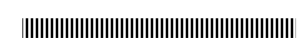

Original Paper

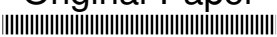

\title{
Condition for Which a Male Student Accepts TV Commercial and Its Examples
}

\author{
TSUJI Yukie \\ Faculty of Management, Otemon Gakuin University, \\ 2-1-15, Nishiai, Ibaragi, Osaka 567-8502, Japan
}

Received 20 June 2005 ; accepted for publication 11 August 2005

\begin{abstract}
There are two purposes in this report. One is to clarify the factor of the advertisement that a male student tends to accept. Although the advertisement is usually watched casually, there must be some message from maker. Another is to give the position to each advertisement on the axes of the obtained factors. For the first purpose, factor analysis using main factor was applied. As the result of the factor analysis, three factors were required and respectively named as transmissibility, novelty and artistic. These results were obtained as the surveyed subjects who were about 280 male students in Kansai region (Hyogo, Kyoto, Osaka, etc.) .

Next, positioning each advertisement was tried using these three factors. This work was participated by 40 male students. For giving the position, they chose the $35 \mathrm{TV}$ advertisements aired since the Heisei. After watching 35 advertisements for thirteen minutes, they evaluated by using tree kinds of marks; $O, \square$ and $\times$.
\end{abstract}

Key Words: TV commercial; Factor analysis; Male students of university; The conditions for accepting

\section{男子大学生がテレビ広告を受け入れる条件とその具体例}

辻幸恵

\section{1. はじめに}

男子大学生の流行をささえる情報のひとつとしてテレ ビ広告に着目をした. テレビ広告は企業にとって, 自社の アイディア，サービス，商標などを広く世間に知らしめる ための情報提供のツールのひとつである，そして，顧客と なる可能性をひめている広告の受け手に良いイメージや インパクトを与えることは，その広告の評価の良し悪しの みには留まらない. テレビ広告は企業イメージや企業の価 值の向上を目的とし，購買機会を促進するものである

つまり，テレビ広告は企業から顧客へのコミュニケーショ ン活動であり，商品に対する啓蒙活動でもある．本報告の 目的は，(1)アンケート調査から得たデータを用いて，男子 大学生のテレビにおける広告の受け入れ条件 (本報告では 以降“要因”とよぶ) を抽出すること，(2)得られた因子を 活用して，具体的にテレビ広告を分類することである。こ
の研究の意義は $2 つ$ つ. ひとつは, 男子大学生に受け入 れられやすいテレビ広告の要素が何を意味しているのか を知ることによって, 彼らの好悪がわかる. 好悪を知る ことによって, 男子大学生に対して好まれるアピール方法 が模索できる. 筆者は男子大学生の流行について継続して 研究している[1-4]が，ここではその流行の源泉のひとつと なるテレビ広告に着目をした. もうひとつは，そこからモ ノやサービスに対して何を求めているのかというニーズ が理解できる. ニーズを知ることによって, 新しい市場開 拓が可能となるのである.

広告を情報とみなしている仁科の研究[5]では，いかに受 け手に伝えられるかということに着目し, 実際の広告に関 してもそれぞれ事例研究（カネボウ, ブリヂストン，J R 東海など）をあげている. 本研究においても個々の事例と しての広告に着目しており，ここであげられているカネボ ウや JR 東海の CM をとりあげている. 広告内の言葉 (キ ッチコピーという) に着目したのは奥山であり, 彼が作成

連絡先 : 追手門学院大学経営学部 567-8502 茨木市西安威 2-1-15, E-mail yukie@res.otemon.ac.jp, FAX 078-871-2413 
した広告に関する辞典がある[6].この辞典には 1978 年か ら 1991 年の 4 年間に揭載された新聞広告のへッドライン に用いられた語彙を見出しとしている。ここに集められた ものがすべてを網羅しているとはいえないかもしれない が，貴重な資料であり，本研究でもこの中の用語を参考に している.

\section{2. 調查対象・方法}

\section{1 予備調查}

調査期間は, 2004 年 10 月中旬である. 大阪市にある私 立大学 (共学) の経営学部に所属する男子大学生 101 名が 対象である. 学年の構成としては 2 回生が 46 人， 3 回生 38 人, 残りが 4 回生以上である. 調査の方法はB 5 サイ ズの紙を配布し，スクリーンに映し出した広告について思 うところを自由に書いてもらうというものである.ここで 使用した広告は，レナウン（あなたのおかげで春・夏：フ アッション), 日清食品 (どん兵衛：インスタント麺), 資 生堂（アクテアハート：化粧品）, 本田技研工業（シビッ ク：自動車），東海旅客鉄道（京都キャンペーン: 旅行), 日本電気(バザールでござーるシリーズ:家電パソコン), キューピー (マヨネーズ: 調味料), サントリー（ピコ： 紅茶飲料）の 8 つである. 視聴時間は合計で 3 分 48 秒で あった．すなわち，これら8つの広告をビデオに収めて， 続けてスクリーンにうつして試写をした. その後, それぞ れの広告に対してどのように感じたかを各自に自由に書 いてもらったのである．記述に対する注意事項としては， なるべく一文を簡潔に書くこととした. 記述調査の結果の 一部を以下に挙げた

レナウン（あなたのおかげで春・夏 : ファッション）は 関心を引く，誰かに話たくなる，もう一度見たい，新奇性 を感じる，斬新さを感じる，カラフル，賑やか，騷がし いなどが書かれ，日清食品（どん兵衛：インスタント麺） は伝えたいことがわかる, 全体の意味がわかる, ひつこい， おやじっぽい，ストーリーがある等の意見が書かれた。資 生堂（アクテアハート：化粧品）は美学を感じる, 芸術的 だ, 商品に興味がわく，大人っぽい，本田技研工業（シビ ック：自動車）注関心を引く，もう一度みたくなる，シン プルである等と書かれた，東海旅客鉄道（京都キャンペー ン: 旅行）は関心を引く，誰かに話たくなる，もう一度見 たくなる，世界観を感じる，バリューがあるという意見を はじめ, 自然, 癒し, 安らぎなど他の CMと比較して一番 多くの記述を集めた. 日本電気 (バザールでござーるシリ 一ズ : 家電) は工夫を感じる，伝えたいことがわかる. キ ューピー(マヨネーズ:調味料) は伝えたいことがわかる, シンプルである，共感できる，工夫を感じる等とある，サ ントリー（ピコ：紅茶飲料）は意味がわかる，もう一度み たくなる，共感できる，芸術的だ，ストーリーがある等で あった.
これらの8つの広告を見て男子大学生たちが感じたこと を以下の 30 にしぼった. それらは, 全体の意味がわかる, 伝えたいことがわかる，シンプルである，共感できる，新 奇性を感じる，関心をひく，商品に興味がわく，驚きがあ る, 誰かに話たくなる, もう一度みたくなる, それらしさ がわかる, 代表的だ, 芸術的だ, 美学を感じる, 工夫を感 じる，斬新さを感じる，カラフル，賑やか，気品がある， 映像に透明感，奇抜である，世界観を感じる，バリューが ある，賑やか，騒がしい，大人っぽい，おやじっぽい，ブ ランドを感じる，おもしろい，映像が美しい，いやされる であった.これらの 30 項目を次の本調查での質問項目と して活用した.

\section{2 本調查}

調查期間は, 2004 年 11 月上旬から下旬にかけて大阪府, 京都府, 奈良県, 兵庫県に在住の男子大学生 268 名を対象 として実施した. 回収率は $63 \%$ であった. 回収率が高い のは，授業を通じての配付・回収を試みたからである. 調 查に用いた質問紙は,フェイスシート 10 項目と 30 の質問 項目の部分とに分かれる. 30 の質問は予備調査の結果か ら作成をした．たとえば回答は「その広告において全体の 意味がわかるということは，あなたが受け入れられるテレ ビ広告の条件にどの程度，当てはまると思いますか小とい 5問いにした。この問いに対して，1から5までの尺度の 中で，各自が当てはまると思ったところを○を付して答え てもらった，尺度は1：まったくそうは思わない，2：や やそうは思わない，3：どちらでもない，4：ややそう思 う，5：まったくそのとおりだと思う，の5段階である. フェイスシートでは性別, 年齢, 居住地域, 通学時間, 1 ケ月のこずかい (自由に使用できるお金)，購読雑誌名，1 日の TV の視聴時間，パソコンの所持状況，恋人（特定の 異性）の有無, アルバイトの状況（している，していない） を尋㱛ている. 分析手法としては主因子法による因子分析 を用いた。

\section{3. 結果と考察}

\section{1 フェイスシートの結果}

通学平均時間：50 分, 利用交通機関：1位は電車， 2 位 はバス，3位は原動機付自転車． 1 ケ月のこづかいの平均 金額 : 26000 円，アルバイトの有無 : アルバイトをしてい るは約 $60 \%$ であった. 1 ケ月の購読雑誌の平均数: 1.5 冊, 購読雑誌名 : カジカジ,メンズノンノ, スプリング, 関西 ウォーカー等. 1 日の TV の視聴平均時間 : 約 42 分，パ ソコン所持状況 : 約 $49 \%$ が所持, 恋人の有無 : 有は約 $40 \%$ であった.

\section{2 因子分析の結果}

因子分析の結果は以下のとおりである. 
Table 1 Factor analysis result

\begin{tabular}{|c|c|c|c|}
\hline Question item & $1^{\text {st }}$ factor & $2^{\text {nd }}$ factor & $3^{\text {rd factor }}$ \\
\hline Understood & 0.85 & -0.10 & 0.11 \\
\hline I want to tell ${ }^{1)}$ & 0.82 & -0.08 & 0.14 \\
\hline Simple & 0.77 & -0.01 & 0.08 \\
\hline Sympathy & 0.65 & 0.18 & -0.10 \\
\hline Novel nature & 0.22 & 0.80 & 0.09 \\
\hline Concern is Pulled & -0.01 & 0.75 & -0.02 \\
\hline Interest(goods) & -0.03 & 0.68 & 0.20 \\
\hline Surprise & -0.04 & 0.67 & 0.12 \\
\hline I want to talk ${ }^{2)}$ & 0.06 & 0.65 & 0.21 \\
\hline I want to watch ${ }^{3)}$ & 0.16 & 0.65 & 0.17 \\
\hline Clear & 0.08 & 0.10 & 0.78 \\
\hline Representation & -0.14 & -0.22 & 0.76 \\
\hline Artistic & -0.19 & 0.22 & 0.71 \\
\hline Aesthetics & -0.19 & 0.10 & 0.65 \\
\hline Device & -0.08 & -0.08 & 0.65 \\
\hline Contribution & 19.2 & 18.5 & 14.3 \\
\hline
\end{tabular}

1) I want to tell others the advertisement that I got the message.

2) I want to talk with someone about the Advertisement.

3) I want to watch the advertisement again.

Table 1 には，より結果がわかりやすくなるために，30 項目の質問のうち，第 4 因子以降を含む項目をのぞき 15 項目を示した. 第 1 因子には「全体の意味がわかる」(0.85), 「伝えたいことがわかるから誰かにつたえたい」(0.82), 「シンプルである」(0.77)，「共感をお持える」(0.65)とい うように，広告の基本である伝達力を評価している。 つま り，何の広告であるのかが，わからなければ，男子大学生 にはその広告は受け入れにくいとも読みとれる. 第2因子 は「新奇性がある」(0.80)，「関心をひく」(0.75)，「興味が ある（商品にたいして)」(0.68)というように，広告そのも のとその商品に対してどのような反応があるか，あるいは 興味をもつかが示されている.また,「驚きがある」(0.67),

「誰かに話がしたい」(0.65)，「もう一度見てみたい」(0.65) というように関心の高さが示されている. 第3因子は「明 快である」(0.78)，「代表的である」，(0.76)「芸術的である」 (0.71)，「美学を感じる」(0.65)，「工夫がある」(0.65)とい うように広告の作品それ自体の質の高さや芸術性, 映像作 品としての良し悪しを感じている.ここでは第 3 因子まで で，52.0\%の累積寄与率を得た．第 4 因子以降は寄与率が $10 \%$ 以下になるので, ここでは第 3 因子までを考察の対象 とした.

\section{3 因子分析からの考察}

男子大学生が広告を受け入れる場合, その広告の「全体 の意味がわかる」，「伝えたいことがわかる」から広告から
「伝えたい」といら意思が読みとれることが第 1 因子にあ げられた。つまり「伝達力」という広告の基本部分の評価 がなされ，そこがクリアーでなければならないことを意味 する.よって第 1 因子を「伝達力」と名づけた，また，第 2 因子は「新奇性」, 第 3 因子は「芸術性」と名づけた。「新 奇性」は何かそこに新しさや発見があり,「芸術性」は映 像の質を反映している. 男子大学生にとっては受け入れの 基淮となった「新奇性」や「芸術性」はある種の現代アー トにも近く，そこには映像作品としての質も評価されてい るといえよう.

\section{3 つの因子を用いた分類}

\section{1 研究の意味}

男子大学生が受け入れるテレビ広告の 3 つの要因をそ れぞれ軸とした，その軸の組み合わせの上にテレビ広告の 具体例をのせて，それを見た男子大学生に対してグループ インタビューを実施した.ここでの研究の意義は男子大学 生に受け入れられや拉広告が, 具体的に映像としてはど のようなものかが明確になる.このような調査は従来企業 内では実施されていた. たとえば，ロート製薬のテレビC Mに関する調査などは『広告コピー概論』(宣伝会議 1993 年) の 15 章 6) で紹介されている[7].

\section{2 調查対象・方法}

調查期間は, 2005 年 1 月上旬から下旬にかけて大阪府, 京都府, 奈良県, 兵庫県に在住の男子大学生 40 名を対象 として実施した。、ずれもグループインタビューで, 各班 8 名ずつ 5 つのグループを形成した. この 5 班を 2 班と 3 班にわけた，2班は調査の際にどのような広告を用いるの かという広告を選択する基準について話あった. その結果, 以下の 5 つの基準がうまれた. (1)ある年だけに偏らない, たとえば1970年だけに放映されたものだけというよ うな選択はこのましくない. (2)ある業態だけの広告にかた よらない. (3)音楽が大きな影響を与えていない. (4)特別な 事件と結びつかないである. (5)平成に入ってから放映され たものとした.

調査に用いた質問紙はフェイスシート 10 項目と因子分 析で得られた「伝達力」「新奇性」「芸術性」の3 要因を用 いた表である. 次に 5 班全員がテレビ広告をビデオにとっ たテープを見て，たとえば伝達力があると判断した場合に は○を，ないと判断した場合にはメを，どちらでもないと 判断した場合は $\triangle$ を記した. 回答は $\triangle \triangle \times の 3$ 種類で評価 をした. 広告は前述した(1)から(5)の方法を考慮して選択し た 35 の広告である.各班が見ている時間は13分であった。 35 の広告は次のとおりである.

サントリー (ウーロン茶), サントリー (ウイスキー), サントリー (ピコ・紅茶)，東海旅客鉄道（京都キャンペ ーン: 旅行)，西日本旅客鉄道（夏のキャンペーン: 旅行）, 
カルピス (飲料), コカ・コーラ (コーラ・飲料), 日清製 粉 (やきそば)，日清製粉 (カップヌードル)，日清製粉 (チ キンラーメン), 資生堂 (シャンプー), カネボウ (口紅), 安田火災 (火災保険), 安田生命 (生命保険), 三井不動産 販売 (リハウス), 富士写真フィルム (カラープリント), ソニー (ゲーム), 永谷園（お茶漬け海苔）, ファーストリ ティリング (ニニクロ), カルビー(ポテトチップス), ト ヨタ (コロナ・自動車)，本田技研工業（シビック：自動 車), 日産 (自動車), リーバイス (ジーンズ)，塩野義製 薬 (薬)，カゴメ(トマトケチャップ)，ケンタッキーフラ イドチキン (フライドチキン), 日本マクドナルド (ハン バーガー)，江崎グリコ(ポッキー)，ボーダフォン（携帯 電話), サントリー (モルッ・ビール), キリン (生茶・飲 料), キリンビール (ラガー・ビール), 日本テレコム (電 話サービス)，森永製菓（ハイソフト）。

得られた結果をもとにしてグループインタビューを用 いて，結果の意味を考察した。

\section{3 点数化}

5 班の全員でそれぞれ 35 の広告に「伝達力」「新奇性」 「芸術性」の 3 要因別に○ $\triangle \times$ を付けたが，ここではそれ らを点数化した. $\bigcirc を 10$ 点, $\triangle$ を 5 点, ×を 1 点とした. その結果の一部を Table 2 に例示寸る.ここでは比較的に 大きな数值を得たものを揭載した. たとえぱ, Table 2 の 1 行目のサントリー (ウーロン茶) ならば伝達力に対して○ が 10 人で 100 点, $\triangle$ が 20 人で 100 点, $\times$ が 10 人で 10 点とカウントして合計が 210 点となっている. $O \triangle \times$ の点 は，あくまで筆者が定めた点である.だから以下の例示で はわずかな点数の差を議論するのではなく, どういうよう な広告が受け入れられているのかという傾向をみる。 その ための点数化である. 最高得点は 400 点になり, 最低得点 は 40 点となる

\section{5. 分類された結果からの考察}

以下に各軸に位置づけた広告の代表的なものを社名で 示した. 数值の基淮としては○は 300 前後，×は 100 末 满とした. また, グループインタビューの中で特に多くの 意見があった広告も示した。

(1)「伝達力」と「新奇性」との 2 軸上での位置関係

Fig. 1 に「伝達力」と「新奇性」との 2 軸上で各象限の 代表的な広告の位置関係を示した。

Table2 Mark of three factors

\begin{tabular}{|c|c|c|c|}
\hline Name & Transmissibility & Novelty & Artistic \\
\hline SUNTORY (oolong tea) & 210 & 330 & 95 \\
\hline SUNTORY (whiskey) & 256 & 280 & 210 \\
\hline SUNTORY(piko tea) & 262 & 95 & 289 \\
\hline SUNTORY(morutu) & 155 & 125 & 95 \\
\hline JR Toukai & 305 & 242 & 332 \\
\hline JR West Japan & 300 & 185 & 95 \\
\hline CALPIS & 205 & 185 & 135 \\
\hline Coca - Cola & 371 & 381 & 351 \\
\hline NISSIN(yakisoba) & 90 & 242 & 95 \\
\hline NISSIN(chickennoodle) & 290 & 285 & 65 \\
\hline NISSIN( cup noodle) & 256 & 300 & 371 \\
\hline SHISEDO & 90 & 220 & 295 \\
\hline Kanebo & 90 & 212 & 290 \\
\hline Yasudakasai & 310 & 80 & 110 \\
\hline Yasudaseimei & 70 & 100 & 80 \\
\hline Mitui & 160 & 110 & 115 \\
\hline FUJIFILM & 300 & 75 & 125 \\
\hline Sony & 360 & 350 & 145 \\
\hline NAGATANIEN & 70 & 285 & 130 \\
\hline FAST RETAILING & 85 & 290 & 140 \\
\hline Calbee & 85 & 85 & 70 \\
\hline TOYOTA & 150 & 305 & 75 \\
\hline Honda & 200 & 310 & 300 \\
\hline Nissan & 120 & 125 & 130 \\
\hline Levi Strauss & 300 & 195 & 300 \\
\hline SIONOGI & 95 & 175 & 295 \\
\hline KAGOME & 300 & 90 & 125 \\
\hline $\mathrm{KFC}$ & 300 & 165 & 95 \\
\hline McDonald's & 295 & 150 & 90 \\
\hline EzakirGliko & 175 & 145 & 105 \\
\hline Vodafon & 80 & 300 & 110 \\
\hline Suntory(morutu) & 155 & 125 & 95 \\
\hline KIRIN & 165 & 105 & 110 \\
\hline KIRIN beer & 175 & 145 & 135 \\
\hline Japan Telecom & 165 & 125 & 120 \\
\hline MORINAGA & 90 & 85 & 95 \\
\hline
\end{tabular}




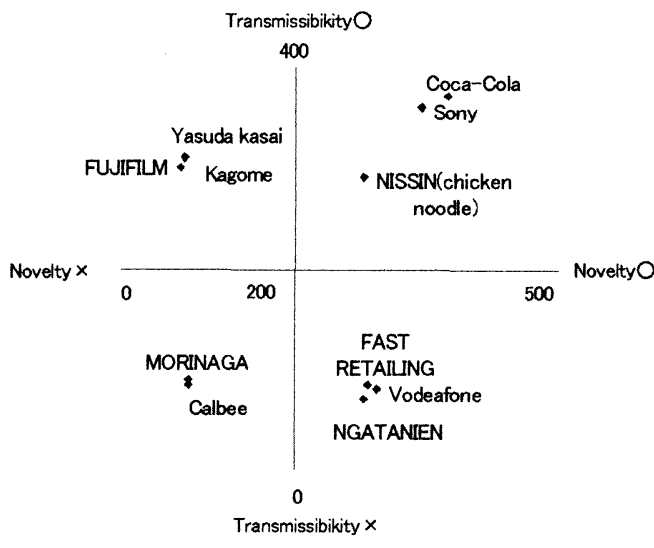

Fig.1 Transmissibility-Novelty

「伝達力」有で「新奇性」有のコカ・コーラとソニーであ った．特に男子大学生にとっては，コカ・コーラの広告へ の評価が高かった，そこには爽やかさを伝える力があり， 映像の切り口も斬新である.ここにはライフスタイルに対 する提案もある.この斬新さが新奇性として認められてい ると考えられる.これに対して安田火災, カゴメ, 富士写 真フィルムは「伝達力」は有るが「新奇性」は無い.これ は実用的であったり，あるいは身近で見慣れた商品である ことが考えられる.「伝達力」無で「新奇性」有の永谷園, ファーストリティリング, ボーダーフォンの広告は一瞬, 何だろうという関心をひく広告であるという意見であっ た.しかし何が言いたいのか惊からないという意見もあ った.「伝達力」無で「新奇性」無のカルビー（ポテトチ ップス）は，商品を見慣れているために新奇性を感じない し，ことさらポテトチップスの良さやおいしさを伝達して いるとは思えないという学生たちの意見であった. よって, 新奇性の有りは切り口の新鮮さ, 無しは見慣れたものであ るといえよう。伝達力の有無は実用性の有無を示すと考え られる。

(2)「新奇性」と「芸術性」との 2 軸上での位置関係

Fig. 2 に「新奇性」と「芸術性」との 2 軸上で各象限の 代表的な広告の位置関係を示した.

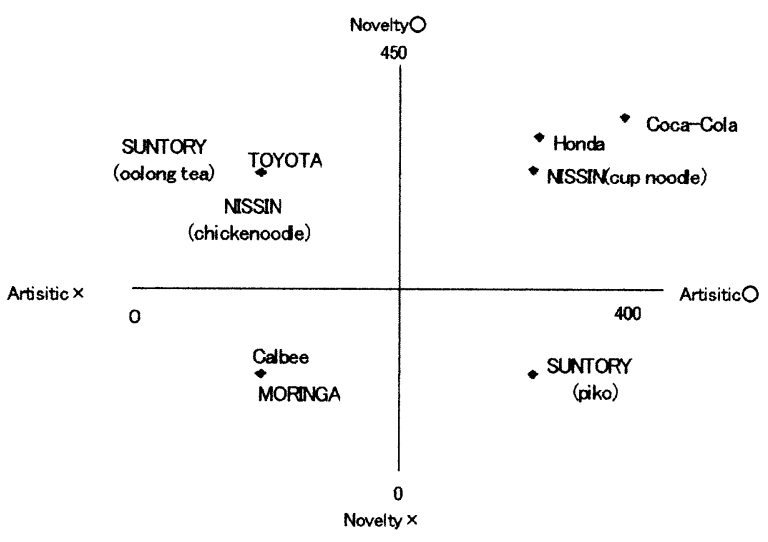

Fig.2 Novelty-Artistic
「新奇性」有で「芸術性」有は, コカ・コーラ, 日清製粉 (カップヌードル), 本田技研工業であった. どちらもス トーリーが明確でそのストリー自体が新しさを含んでい る. カップヌードルは特に映像も芸術的な色彩をおびてい る.「新奇性」有で「芸術性」無は日清チキンラーメン, トヨタ,サントリー (ウーロン茶) であった.サントリー は若い中国人を採用したといらその発想が新鮮であった。 しかし広告の背景の映像が山河で, 平凡な印象があり, 芸 術性があるとは言えないと大学生たちに判断されたので ある. 同時に何であろうと思わせる日清製粉（チキンラー メン）にしても芸術性を感じるには至っていない。「新奇 性」無で「芸術性」有はサントリー（紅茶のピコ）であつ た。これは映像から受ける英国らしさが芸術性として評価 されたと考えられる. また, 日清製粉（カップラーメン） も芸術性が高い. マンモスと原始人とのやりとりというス トーリーであるが，その映像に心ひかれるものがあるので あろう。「新奇性」無で「芸術性」無は森永製菓のハイソ フトで，この製品においては，菓子以上の期待されるもの はないと考えられる. カルビーも同様である. 新奇性や芸 術性というものは, あまりによく知られている商品には新 鮮さがないように，身近すぎるものや定番には，ないよう な要素なのかもしれない，もしもテレビ広告で菓子などの ような商品が, 男子大学生に受け入れてもらえるような工 夫をするとしたら，かなりのレベルの高い映像を供給する 必要があると考えられる. よって芸術性の有無は, その映 像の美と発想のレベルの高さだと言える. 美しい山河であ っても, それだけの背景では芸術とは言えず, 何か別の次 元の美が必要なのである. それは新しい価值観を含む必要 もある。

(3)「芸術性」と「伝達力」との 2 軸上での位置関係 Fig.3 に「芸術性」と「伝達力」との 2 軸上で各象限の代表的な 広告の位置関係を示した。

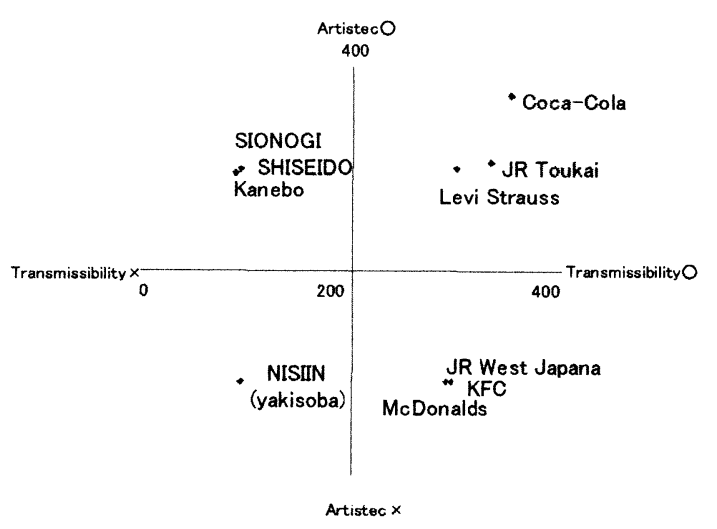

Fig.3 Artistic-Transmissibility 
「芸術性」有で「伝達力」有のリーバイスや東海旅客鉄道 は若者のおしやれさが伝わり，関心があるということにな る.「芸術性」有で「伝達力」無はカネボウ, 塩野義製薬, 資生堂であるが, 男子大学生には化粧品や楽にさほど興味 があるとはいえない対象であるので, 伝達力が無いという 判断になった可能性もある. よって「伝達力」の有無には 関心の有無も関倸している.「芸術性」無で「伝達力」有 は日本マクドナルド，J R 西日本，ケンタッキーは強烈に その商品がどういうものかという伝達はされるが，そこに は芸術的なところはないといら判断であった。「芸術性」 無で「伝達力」無は安田生命, 日清製粉（やきそば）は どちらかといえば, 堅実な広告で, 心にうったえてくるも のが少なかったと考えられる. よって, 定番的な商品は伝 達力が低くなっている傾向にあった。

\section{6. まとめ}

男子大学生の流行をささえる情報のひとつとしてテレ ビ広告に着目をした８つの広告を見て，受け入れやすさ についての自由記述をしてもらい，男子大学生が感じてい る広告に対するイメージを 30 の項目としてまとめた．そ こから男子大学生が広告を受け入れる基準を見出すため に因子分析を用いた. その結果, 「伝達力」「新奇性」「芸 術性」の 3 要因が得られた。 それらの要因を軸とみなして 2 軸の組み合わせをつくり，それぞれの軸上に位置づけた
ところ、「伝達力」有無は関心の有無にも影響されていた. また，「伝達力」があって,「新奇性」のないものは実用的 なものであるとも考えられた。「新奇性」有は切り口の新 鮮さが見出された．無しは見慣れたものであった，「芸術 性」有は映像の色のトーンなどのような映像の美以外にも 発想の良さが必要であった. また, 「芸術性」と「伝達力」 のないものは定番的な商品であることもわかった.

\section{References}

[1] Tsuji, Y., Kazama, K.; Journal of the Japan Research Association for Textile End-Use, 41, pp.895 (2000)

[2] Tsuji, Y., Kazama, K.; Journal of the Japan Research Association for Textile End-Use, 42, pp.775 (2001)

[3] Tsuji, Y., Kazama, K.; Journal of the Japan Research Association for Textile End-Use, 43, pp.697 (2002)

[4] Tsuji, Y., Kazama, K.; Journal of the Japan Research Association for Textile End-Use, 45, pp.358 (2004)

[5] Nishina, S.; "Advertisement Effect", p. 160, Dentu (2001)

[6] Okuyama, M.; "Dictionary of Catchphrase" p.425, Tokyou-shuppan (1992)

[7] Uejyo, M.; "Introductiono Adertisemetphrase", p.170, Sendenkaigi (1993) 